\title{
Relative Rooting Depths of Native Grasses and Amenity Grasses with Potential for Use on Roadsides in New England
}

\author{
Rebecca Nelson Brown', Cynthia Percivalle, Sophia Narkiewicz, \\ and Samantha DeCuollo \\ Department of Plant Sciences, University of Rhode Island, 210 Woodward \\ Hall, Kingston, RI 02881
}

Additional index words. Festuca rubra, Sorghastrum nutans, Panicum virgatum, Andropogon gerardii, Festuca brevipila, Elymus canadensis, Elymus virginicus, Elymus villosus, Elymus hystrix, Panicum amarum, Pucciniellia distans, Festuca arundinacea, Lolium perenne, Agrostis perennans, Schizachyrium scoparium, Deschampsia cespitosa, Muhlenbergia schreberi, Eragrostis spectabilis, Bouteloua courtipendula, Koeleria macrantha, Sporobolous cryptandrous, Bromus inermis

\begin{abstract}
Erosion is a significant problem on highway embankments in Rhode Island. At present, a mixture of red fescue (Festuca rubra L.), perennial ryegrass (Lolium perenne L.), and kentucky bluegrass (Poa pratensis L.) is planted to stabilize the soil. However, only the red fescue survives long term on slopes. Red fescue is shallow-rooted, leading to sod sloughing after heavy rains. The objective of this study was to compare the rooting depth, plant height, and adaptation to roadside conditions of 16 native grasses and five amenity grasses with red fescue to identify species that could be used to reduce sod sloughing. Research was conducted from May 2006 through Aug. 2009 in the greenhouse at the University of Rhode Island in Kingston and on the shoulder of state Route 4 in North Kingstown, RI. The cool-season grasses smooth brome (Bromus inermis Leyss. ssp. inermis), Pumpelly's brome [Bromus inermis Leyss. ssp. pumpellianus (Scribn.) Wagnon], Canadian wildrye (Elymus canadensis L.), Virginia wildrye (Elymus virginicus L.), silky wildrye (Elymus villosus Muhl. ex Wild.), eastern bottlebrush (Elymus hystrix L.), perennial ryegrass, and tall fescue (Festuca arundinacea $\mathrm{L}$.) and the warm-season grasses little bluestem [Schizachyrium scoparium (Michx.) Nash] and purple lovegrass [Eragrostis spectabilis (Pursh.) Steud.] were similar in height to red fescue while rooting significantly more deeply. Of these 10 species, little bluestem, purple lovegrass, and tall fescue showed the best survival on the roadside.
\end{abstract}

Slopes in highway right-of-ways in Rhode Island and much of New England are commonly seeded with a grass-legume mixture, which is predominantly red fescue (RIDOT, 2004). Red fescue is preferred for roadside use because it is drought-tolerant and thrives on acidic, infertile soil. Roadside embankments are generally constructed of subsoil and gravel, over which 2 to 6 inches $(5$ to $15 \mathrm{~cm})$ of topsoil is spread as a distinct layer (RIDOT, 2004). The subsoils are very stony with coarse-textured loamy sand between the

\footnotetext{
Received for publication 1 Oct. 2009. Accepted for publication 14 Jan. 2010.

This research was funded by a grant from the Rhode Island Department of Transportation. Seed was donated by Calvin Ernst of Ernst Conservation Seeds, Martin van der Grinten of the Big Flats Plant Materials Center, and the National Plant Germplasm Repository.

We thank Carl Sawyer for technical assistance, Jessica Gilbert and Peter Fish for assistance with root washing, and David Brown for assistance with the figures.

${ }^{1}$ To whom reprint requests should be addressed; e-mail brownreb@uri.edu.
}

rocks. The topsoil ranges from mediumtextured silt to sand (Wright and Sautter, 1988). Red fescue is shallow-rooted with most of the root mass confined to the topsoil layer (Beard, 1989). When root growth is concentrated in a shallow mat with a sharp boundary in the soil profile, slope failure is likely to occur beneath the mat (Simon and Collison, 2002). This sloughing of the sod and topsoil layer is precisely the type of slope failure that occurs along roadsides in Rhode Island, particularly when the turf cover at the top of the bank has been rutted by vehicles (C. Franco, personal communication). A more even distribution of root mass with depth provides better slope stabilization (Simon and Collison, 2002).

Gray and Sotir (1996) report that established grasses reduce surface erosion by $90 \%$ or more over bare ground. They also report that roots effectively increase the shear strength of soil, decreasing the likelihood that the soil will slip, and that fine roots are more effective than thick roots at binding soil. In a study of the effectiveness of different vegetation types at preventing slip events on stream banks, Simon and Collison (2002) reported that eastern gamma grass
[Tripsacum dactyloides (L.) L.] was as effective as any of the tree species studied at mechanically stabilizing soil and that switchgrass was significantly more effective. Beard (1989) reported that bermudagrass [Cynodon dactylon (L.) Pers.] was the most deeply rooted of the commonly used turfgrasses with a depth of more than $2.5 \mathrm{~m}$ under mowed conditions. Fairway wheatgrass [Agropyron cristatum (L.) Gaertn.] and tall fescue were the most deeply rooted of the cool-season grasses. In a study of 16 tall fescue cultivars and lines, Kim et al. (1999) found that all entries rooted to $60-\mathrm{cm}$ depth, and five entries rooted to $75-\mathrm{cm}$ depth. There was no difference in rooting depth between tall forage types and lower-growing turf or dwarf types when plants were clipped. Sprague (1933) found that almost all the roots of kentucky bluegrass and multiple species of bentgrass (Agrostis spp.) occurred in the top $10 \mathrm{~cm}$ of the soil profile, whereas hard fescue had a more even root distribution and that weekly mowing at lawn height versus annual mowing did not affect rooting depth in mowingtolerant species. Stuckey (1941) found that roots of perennial ryegrass and several other species were annual, whereas those of kentucky bluegrass were perennial. Weaver (1968) reported that roots of the common prairie grasses were perennial. Weaver (1968) extensively studied the root growth of native prairie grasses and midwestern range and pasture grasses in the first half of the 20th century, including some of the grasses in this study. However, the deep soils of the midwestern prairie are very different from the soils of the eastern seaboard (Sprague, 1933). Studies of grass rooting depth in eastern soils have focused on the podzolic agricultural soils and typical turfgrass species (Sprague, 1933; Stuckey, 1941). Little is known about the rooting patterns of eastern ecotypes of the prairie grasses studied by Weaver (1968) or about the rooting patterns of the eastern native grass species not found in the prairie.

The objective of this study was to identify alternative grass species that root more deeply than red fescue without producing significantly more top growth. Particular emphasis was placed on grasses native to southern New England because national highway policy strongly encourages the use of native vegetation in highway right-ofways (Clinton, 1999).

\section{Materials and Methods}

Plant materials. Twenty-two grass species were included in this study. Specific details, including seed sources and native status, are presented in Table 1. Two of the grasses used, perennial ryegrass (Lolium perenne L.) and red fescue, are components of the seeding mixes currently used on roadsides in New England. Red fescue is native to New England (USDA-NRCS, 2009), although the seed normally used on roadsides is a cultivated type from Canada. Tall fescue and smooth brome have been 
Table 1. Grass species used in the rooting depth studies and the roadside trials, including native status, type of photosynthesis, and seed sources.

\begin{tabular}{|c|c|c|c|c|c|}
\hline Common name & Species & Type $^{z}$ & Status $^{\mathrm{y}}$ & Accession & Source $^{\mathrm{x}}$ \\
\hline Big bluestem & Andropogon gerardii & $\mathrm{C} 4$ & Native & New England ecotype & BFPMC \\
\hline Autumn bentgrass & Agrostis perennans & C3 & Native & Commercial & ECS \\
\hline Smooth brome & Bromus inermis ssp. inermis & C3 & Introduced & Commercial & ECS \\
\hline Pumpelly’s brome & Bromus inermis ssp. pumpellianus & $\mathrm{C} 3$ & Native & $\begin{array}{l}\text { PI accessions } 196321,655132,19749, \\
19743 \text {, and } 372670\end{array}$ & W-6 \\
\hline Hairgrass & Deschampsia cespitosa & C3 & Native and introduced & PI 241051 and commercial & W-6, ECS \\
\hline Eastern bottlebrush & Elymus hystrix & C3 & Native & PI 531615 & W-6 \\
\hline Canadian wildrye & Elymus canadensis & $\mathrm{C} 3$ & Native & Iowa ecotype & BFPMC \\
\hline Virginia wildrye & Elymus virginicus & C3 & Native & Pennsylvania ecotype & BFPMC \\
\hline Silky wildrye & Elymus villosus & $\mathrm{C} 3$ & Native & PI 531703 & W-6 \\
\hline Tall fescue & Festuca arundinacea & C3 & Introduced & Cultivars Rebel and Bladerunner & ASS \\
\hline Hard fescue & Festuca brevipila & $\mathrm{C} 3$ & Introduced & Cultivar Durar & BFPMC \\
\hline Red fescue & Festuca rubra & C3 & Native and introduced & Common creeping red & ASS \\
\hline Indiangrass & Sorghastrum nutans & $\mathrm{C} 4$ & Native & PI 591811 and cultivar NE54 & PGRCU, ECS \\
\hline Little bluestem & Schizachyrium scoparium & $\mathrm{C} 4$ & Native & Connecticut ecotype, cultivar Aldous & ECS \\
\hline Panic grass & Panicum amarum & $\mathrm{C} 4$ & Native & Cultivar Atlantic & BFPMC \\
\hline Switchgrass & Panicum virgatum & $\mathrm{C} 4$ & Native & PI 414069 and cultivar Cave-in-Rock & PGRCU, ECS \\
\hline Nimblewill & Muhlenbergia schreberi & $\mathrm{C} 4$ & Native & Commercial & ECS \\
\hline Alkaligrass & Puccinellia distans & C3 & Introduced & PI 443386, cultivar Fults & W-6, ECS \\
\hline Perennial ryegrass & Lolium perenne & $\mathrm{C} 3$ & Introduced & Cultivars Palmer IV and Line Drive & ASS \\
\hline Purple lovegrass & Eragrostis spectabilis & $\mathrm{C} 4$ & Native & RI ecotype, FL ecotype & Roadside, ECS \\
\hline Sideoats grama & Bouteloua curtipendula & $\mathrm{C} 4$ & Native & Commercial & ECS \\
\hline Sand dropseed & Sporobolus cryptandrous & C4 & Native & Commercial & ECS \\
\hline Prairie junegrass & Koeleria macrantha & $\mathrm{C} 3$ & Native and introduced & Cultivar Barleria & Barenbrug \\
\hline
\end{tabular}

"C4 grasses are commonly known as "warm-season" and C3 grasses as "cool-season."

${ }^{y}$ Status refers to whether the species is native or introduced in New England and is based on the PLANTS database and the Flora of North America.

${ }^{\mathrm{x} B F P M C}=$ Big Flats Plant Materials Center, USDA-NRCS, Corning, NY; ECS = Ernst Conservation Seeds, Meadville, PA; W-6 = Western Regional Plant Introduction Station, USDA-ARS, Pullman, WA; PGRCU = Plant Genetic Resources Conservation Unit, USDA-ARS, Griffin, GA; ASS = Allens' Seed Store, Exeter, RI.

Table 2. Plant size data for Expt. $1 .^{\mathrm{z}}$

\begin{tabular}{lcccc}
\hline Species & Replications & Plant ht $(\mathrm{cm})$ & Rooting depth $(\mathrm{cm})$ & Root mass $(\mathrm{g})$ \\
\hline Smooth brome & 9 & 44.3 & 62.5 & 3.4 \\
Eastern bottlebrush & 3 & 30.6 & 40.5 & 0.8 \\
Red fescue & 10 & 27.9 & 33.4 & 0.5 \\
Indiangrass & 10 & 57.0 & 73.7 & 4.7 \\
Little bluestem & 2 & 24.2 & 64.6 & 0.5 \\
Alkali grass & 3 & 33.0 & 30.4 & 0.4 \\
Switchgrass & 6 & 82.9 & 70.9 & 4.1 \\
\hline
\end{tabular}

${ }^{\mathrm{z}}$ All values are means; least significant difference values are 7.9, 13.5, and 2.9 for height, depth, and mass, respectively.

widely used on roadsides, although they are less commonly used in New England. Bromus inermis subsp. pumpellianus is native to New England (USDA-NRCS, 2009), where it was historically common on rocky, infertile sites. Bromus inermis subsp. inermis is introduced from Eurasia and naturalized. The two subspecies are known to intercross freely and cannot be distinguished from vegetative parts (Elliott, 1949). Hard fescue is a naturalized species that is extremely stress-tolerant and is often used for erosion control on unmown slopes. Alkalai grass [Puccinellia distans (Jacq.) Parl.] is another naturalized species that is extremely salt-tolerant and increasingly used in roadside mixes. Switchgrass (Panicum virgatum L.), little bluestem [Schizachyrium scoparium (Michx.) Nash], indiangrass [Sorghastrum nutans (L.) Nash], broomsedge (Andropogon virginicus L.), and big bluestem (Andropogon gerardii Vitman) are all warm-season prairie grasses that have been widely used for roadside plantings in the Midwest and wildlife plantings in the Northeast. Bitter panic grass (Panicum amarum Elliot), sideoats grama [Bouteloua curtipendula (Michx.) Torr.], sand dropseed [Sporobolus cryptandrus (Torr.) A. Gray], nimblewill (Muhlenbergia schreberi J. F. Gmel.), and purple lovegrass [Eragrostis spectabilis (Pursh.) Steud.] are warm-season grasses native to New England. The wildryes, autumn bentgrass [Agrostis perennans (Walt.) Tuckerman], junegrass [Koeleria macrantha (Ledeb.) Schult.], and hairgrass [Deschampsia cespitosa (L.) Beauv.] are all native coolseason grasses. For the native grasses, we used seed of New England ecotypes when possible; otherwise, we used seed from the closest available geographic location.

Plant culture for rooting depth. Rooting columns were constructed after Schaeffer et al. (1994). Briefly, a 76-cm length of 10$\mathrm{cm}$ diameter white polyvinyl chloride drain pipe was fitted with a perforated cap on one end. Pea gravel was placed in the bottom of the tube to a depth of $2 \mathrm{~cm}$. The tube was filled with sand, which was tamped down and topped with a 5-cm layer of topsoil (Bridgehampton silt loam). This growth medium presents physical resistance to root penetration comparable to the sandy soil between the rocks at the roadside trial site and replicates the sharp boundary between subsoil and topsoil. We acknowledge that these conditions may reduce the applicability of our results to sites with compacted subsoil high in clay. Plants were grown for only a single season although some species have perennial roots.

The study was conducted in the greenhouse at the Skogley Turf Research Center of the University of Rhode Island in the Summer and Fall of 2006 and 2008. Temperatures were in the range of 26 to $32{ }^{\circ} \mathrm{C}$ during the day and 10 to $15^{\circ} \mathrm{C}$ at night; no supplemental lighting was used. The seeds were germinated on filter paper in petri dishes. Once the seedlings had two fully expanded leaves, they were transplanted to the rooting columns with four seedlings per column. All seeds for each experiment were started at the same time, but differences in germination and seedling growth rates among species resulted in transplanting occurring over a 3- to 4-week period for each experiment. Expt. 1 was transplanted 22 June to 14 July 2006 and harvested 2 to 22 Sept. 2006. Expt. 2 was transplanted 15 Aug. to 5 Sept. 2006 and harvested 30 Oct. to 22 Nov. 2006. Expt. 3 was transplanted 15 May to 15 June 2008 and harvested 22 Aug. to 20 Nov. 2008. This experiment ran for 14 weeks instead of 10 weeks to expose plants to both early summer and late summer day lengths and because of concerns that 10 weeks was insufficient for full development of the perennial root systems typical of warm-season prairie grasses. All plants were fully established and tillered at harvest. Plants were fertilized weekly with Hoagland's solution (Hoagland, 1950) containing half-strength macronutrients and full-strength micronutrients. Supplemental irrigation with tap water was applied whenever leaves began to fold or roll, indicating drought stress. All irrigation (including Hoagland's solution) was applied until the solution drained from the holes in the bottom of the rooting column. 
Columns were harvested in the order in which they had been planted. At harvest, the tube was uncapped and the soil column removed intact. Plant height was measured and the foliage was removed at the crown. The soil column was cut into 10 equal sections, each $10 \mathrm{~cm}$ diameter $\times 7.6 \mathrm{~cm}$ high. Roots were washed clean of sand in a hydropneumatic root washer (Gillison's Variety Fabrication, Benzonia, MI) and air-dried before weighing. The hydropneumatic root washer separates roots from the growth medium using differences in bulk density rather than size. This prevents the loss of small roots that can occur with screens.

Roadside survival studies. Two trials were established on the shoulder of Rhode Island state Highway 4 in North Kingstown. Route 4 is a limited access suburban highway; the shoulder consists of a front slope running from the pavement down to a swale and a steep back slope running up to a parking lot. Fourteen native grass species were seeded into $3 \mathrm{~m} \times 1.6-\mathrm{m}$ plots on the back slope in May 2007 (Table 2). Some species were represented by multiple cultivars for a total of 18 entries. Before seeding, existing vegetation was killed with glyphosate herbicide, the soil was tilled to a depth of $6 \mathrm{~cm}$, and rocks were cleared to create a seedbed. Plots were seeded by hand, and the entire trial was hydromulched using a mix of hydrostraw (HydroStraw LLC., Manteno, IL) and 19N19P-19K fertilizer applied with a Finn T-50 HydroSeeder (Finn Corp, Fairfield, OH). No additional fertilizer or irrigation was applied. A severe drought in July and Aug. 2007 reduced establishment of the trial, so the seeded plots were supplemented with transplants. The transplants were produced in the greenhouse at the University of Rhode Island and transplanted by hand in May 2008. A second trial containing 11 cool-season grass species was established on the front slope in Sept. 2007 (Table 3). Again, some species were represented by multiple cultivars for a total of 25 entries. The establishment protocol was the same as for the earlier trial except that the plots were irrigated once during establishment to ensure that all species germinated successfully. The trials were mowed once a year in the fall by Rhode Island Department of Transportation maintenance crews.

Experimental design for rooting depth. The three experiments were analyzed separately. Each experiment used a completely randomized design with unequal replication; replication numbers for each entry are shown in Figures 1 through 3. The experimental unit was a column containing four plants. Red fescue was included as a standard in all experiments; the principal comparisons were between red fescue and the other species. Experiment was a significant factor when the red fescue data were pooled across experiments $(P<0.001)$, confirming our decision to analyze each experiment independently. Significant differences between species were detected using Welch's variance-weighted analysis of variance followed by Fisher's protected least significant difference test to compare means (SAS, 2007). A one-tailed distribution $(\alpha=0.01)$ was used for means comparison with identify species with plant height similar to red fescue, deeper roots, and a more even root distribution. Root weight data for each column section was transformed as a percent of the total root weight for the column to permit comparisons between species differing in total root mass. The difference in percent root mass between the top-most column section and the bottommost section was used as an indication of root distribution with smaller differences indicating more even distribution of roots throughout the soil volume. In Expt. 3, Pumpelly's

Table 3. Plant size data for Expt. 2. ${ }^{\text {. }}$

\begin{tabular}{lcccc}
\hline Species & Replications & Plant ht $(\mathrm{cm})$ & Rooting depth $(\mathrm{cm})$ & Root mass $(\mathrm{g})$ \\
\hline Big bluestem & 3 & 54.4 & 76.0 & 1.4 \\
Autumn bentgrass & 4 & 24.6 & 39.9 & 0.5 \\
Hairgrass & 4 & 17.9 & 20.9 & 0.2 \\
Hard fescue & 4 & 17.5 & 51.3 & 1.8 \\
Canada wildrye & 4 & 21.9 & 76.0 & 2.3 \\
Eastern bottlebrush & 4 & 23.2 & 58.9 & 1.8 \\
Silky wildrye & 4 & 19.5 & 76.0 & 2.8 \\
Virginia wildrye & 4 & 23.3 & 76.0 & 1.8 \\
Red fescue & 4 & 21.6 & 34.2 & 0.3 \\
Indiangrass & 4 & 23.3 & 47.5 & 0.5 \\
Tall fescue & 6 & 19.7 & 50.7 & 0.5 \\
Little bluestem & 2 & 19.7 & 45.6 & 0.2 \\
Nimblewill & 4 & 17.1 & 26.6 & 0.2 \\
Bitter panicgrass & 4 & 54.0 & 76.0 & 1.7 \\
Alkali grass & 4 & 20.5 & 58.9 & 1.1 \\
Perennial ryegrass & 6 & 19.8 & 45.6 & 0.5 \\
\hline
\end{tabular}

${ }^{2}$ All values are means; least significant difference values are 9.6, 18.0, and 1.0 for height, depth, and mass, respectively.
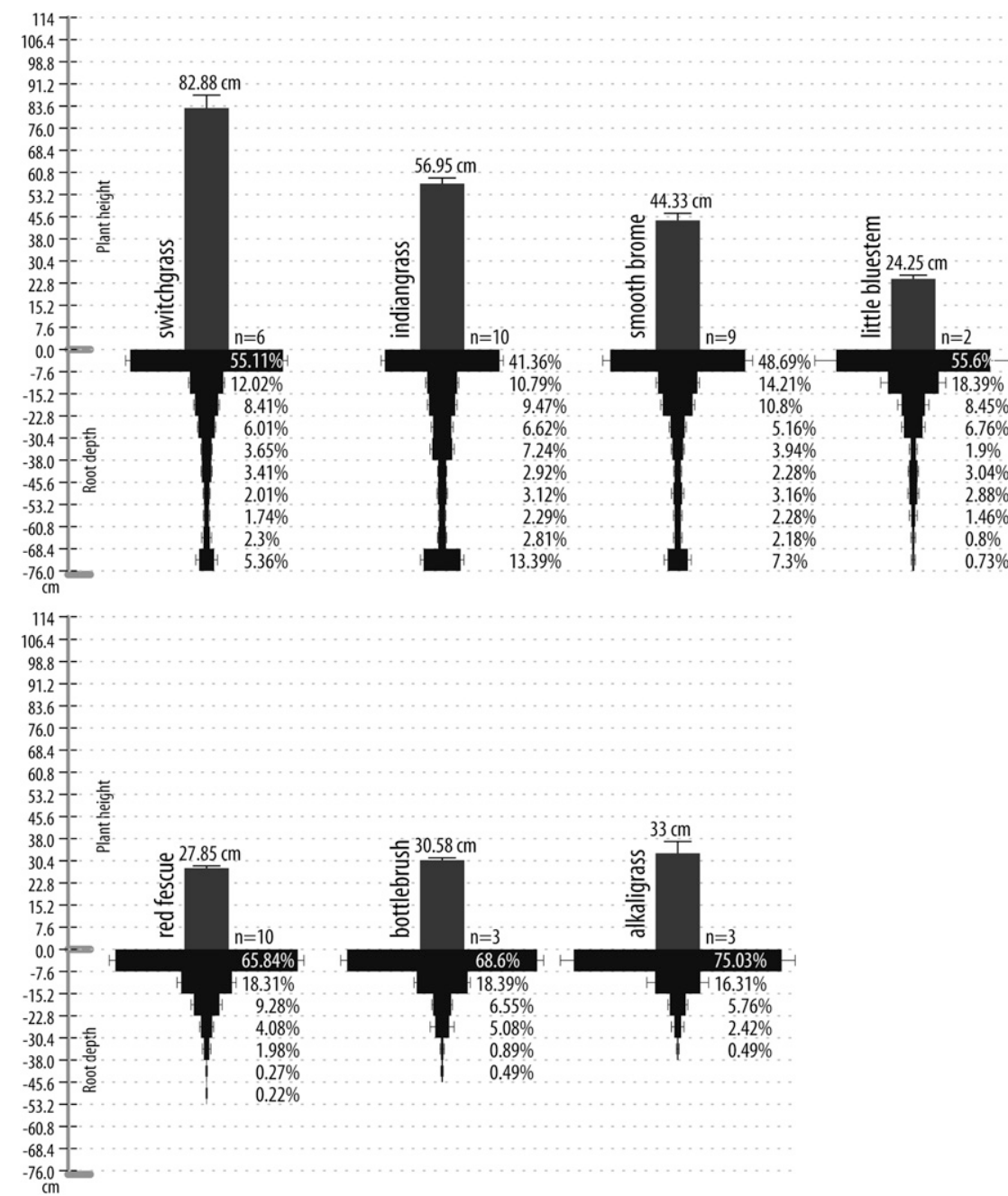

Fig. 1. Plant height, root depth, and root mass distribution for grasses in Expt. 1. The experimental unit was a rooting column containing four plants; $n$ indicates the number of columns (replications). The horizontal bars indicate the percentage of the total root mass at each depth. 
brome, hairgrass, and switchgrass were represented by multiple accessions. The differences between accessions were not significant; data were pooled across accessions to represent the species.

Experimental design for roadside survival studies. The roadside trials were designed as randomized complete blocks with three replications. All plots in each trial were located the same distance from the roadway to reduce variability. Grass survival in the front slope trial was measured using visual rating of percent green cover in the spring, summer, and fall of each year. Competition from crabgrass made it difficult to accurately assess percent cover on the back slope, so stand density was rated on a 0 to 4 scale in late summer and fall when inflorescences were present. A rating of 0 indicated no stand; 4 indicated a dense stand throughout the plot.

\section{Results and Discussion}

Environmental conditions differed among the three experiments, particularly light duration and intensity. Day length is known to affect both shoot and root growth in grasses as well as the partitioning of resources between shoots and roots (Harper et al., 1991). However, the overall root morphology, including the distribution of roots at different
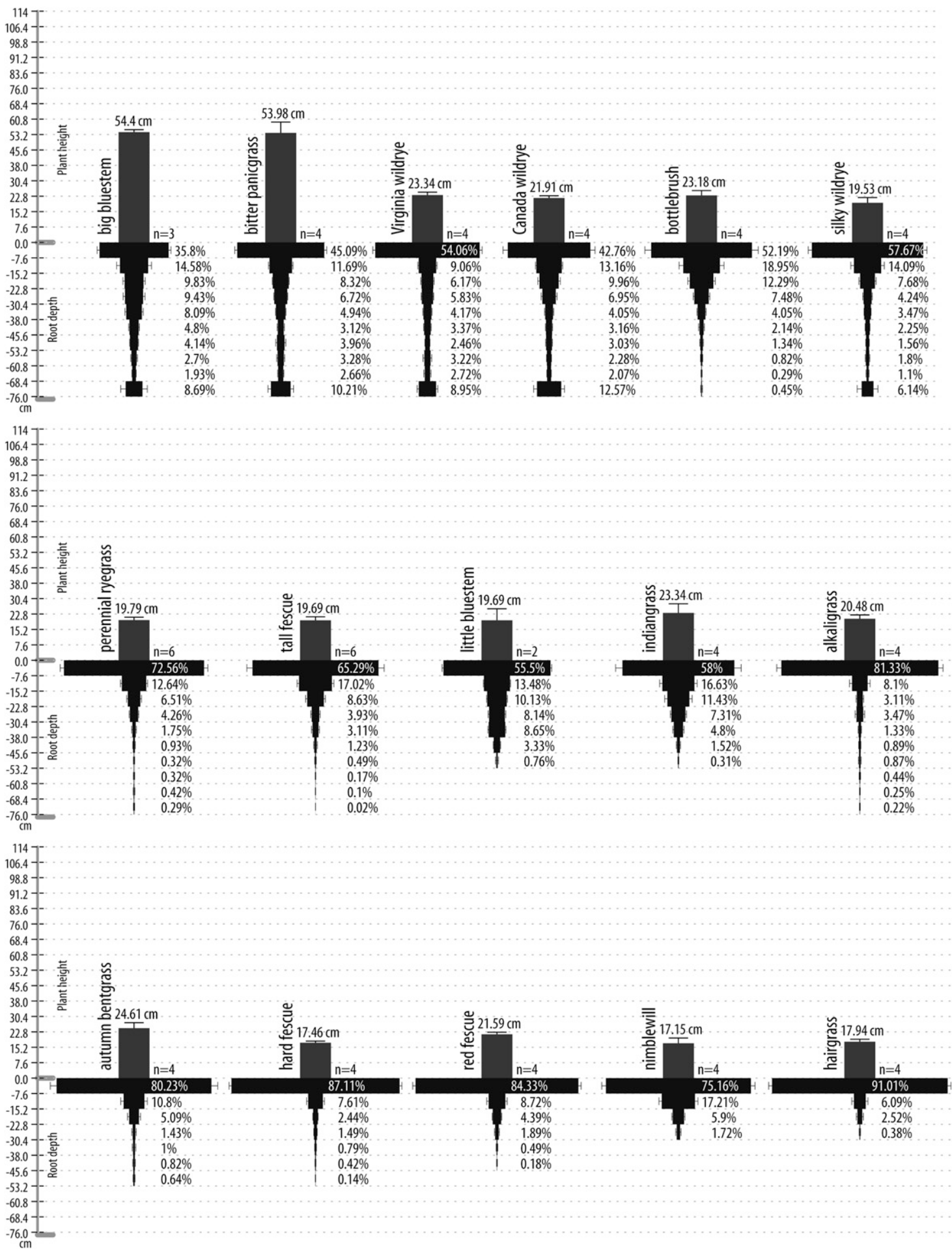

Fig. 2. Plant height, root depth, and root mass distribution for grasses in Expt. 2. The experimental unit was a rooting column containing four plants; $n$ indicates the number of columns (replications). The horizontal bars indicate the percentage of the total root mass at each depth. 
levels in the soil, is controlled by genetics and the soil environment (Harper et al., 1991). The effects of day length were particularly noticeable in the warm-season grasses, which flower in response to decreasing day length. Perennial cool-season grasses normally flower in response to vernalization followed by increasing day length; none of the plants in this study flowered because they had not been vernalized. Plant height, total root depth, and distri- bution of root mass through the soil column are shown in Figures 1 through 3. Plant height and rooting depth were positively correlated in all experiments with $r$ values of $0.70,0.46$, and 0.47 for Expts. 1, 2, and 3, respectively. The higher correlation value in Expt. 1 is most likely the result of none of the grasses flowering in that experiment.

In Expt. 1, red fescue grew to a height of $27.8 \mathrm{~cm}$ and rooted to a depth of $33.4 \mathrm{~cm}$ with
$65.8 \%$ of the root mass in the top $7.6 \mathrm{~cm}$ of the soil column and only $0.5 \%$ in the bottom $38 \mathrm{~cm}$ (Table 2; Fig. 1). Smooth brome, indiangrass, little bluestem, and switchgrass all rooted more deeply than red fescue, and smooth brome, indiangrass, and switchgrass had larger root systems $(P<0.01$; Table 2$)$. Alkaligrass, bottlebrush, and little bluestem were similar in height to red fescue. The other species were significantly taller than red
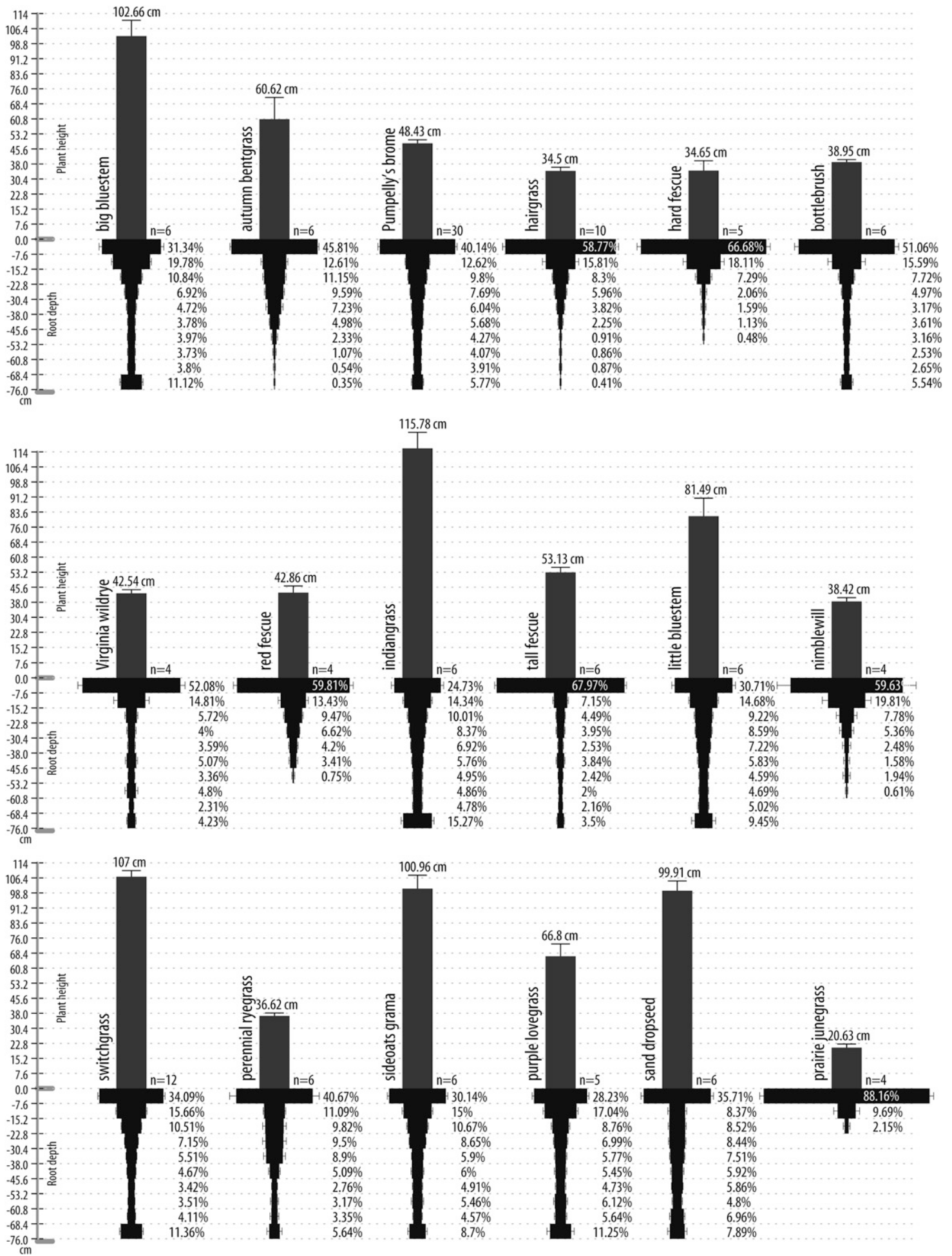

Fig. 3. Plant height, root depth, and root mass distribution for grasses in Expt. 3. The experimental unit was a rooting column containing four plants; $n$ indicates the number of columns (replications). The horizontal bars indicate the percentage of the total root mass at each depth. 
fescue $(P<0.01$; Table 2$)$. Smooth brome, indiangrass, and switchgrass had $17.2 \%$, $24.5 \%$, and $14.8 \%$, respectively, of their roots in the bottom $38 \mathrm{~cm}$ of the soil profile (Fig. 1). The difference from red fescue was not significant for switchgrass because of high variability among the replicates.

In Expt. 2, red fescue grew to a height of $21.6 \mathrm{~cm}$ and rooted to a depth of $34.2 \mathrm{~cm}$ with $84.3 \%$ of the root mass in the top $7.6 \mathrm{~cm}$ of the soil column and only $0.2 \%$ in the bottom $38 \mathrm{~cm}$ (Table 3; Fig. 2). Only big bluestem and bitter panicgrass were significantly taller than red fescue $(P<0.01$; Table 3$)$. Seven species rooted significantly more deeply than red fescue $(P<0.01$; Table 3$)$ : big bluestem, Canada wildrye, bottlebrush, silky wildrye, Virginia wildrye, bitter panicgrass, and alkaligrass. The other species were similar in rooting depth to red fescue. All of these species also had larger root systems than red fescue with the exception of alkaligrass $(P<0.01$; Table 3$)$. Species with a significantly greater percentage of their roots in the lower half of the soil profile $(P<0.01$; Fig. 2$)$ were big bluestem, Canada wildrye, bottlebrush, silky wildrye, Virginia wildrye, indiangrass, little bluestem, and bitter panic grass.

In Expt. 3, red fescue grew to a height of $42.8 \mathrm{~cm}$ and rooted to a depth of $47.5 \mathrm{~cm}$ with $61.1 \%$ of the root mass in the top $7.6 \mathrm{~cm}$ of the soil column and $4.2 \%$ in the bottom $38 \mathrm{~cm}$ (Table 4; Fig. 3). Rooting depth and plant height were greater overall in Expt. 3, probably because the plants remained in the tubes for an additional month. Thirteen species rooted more deeply than red fescue; all differences were significant $(P<0.01$; Table $4)$. Eight species were similar in height to red fescue, whereas junegrass was significantly shorter $(P<0.01$; Table 4$)$. Five species were similar in height to red fescue and had significantly greater rooting depth: Pumpelly's brome, bottlebrush, Virgina wildrye, tall fescue, and perennial ryegrass (Fig. 3). Bottlebrush and tall fescue had significantly larger root systems $(P<0.01$; Table 4$)$. Pumpelly's brome, bottlebrush, and Virginia wildrye had greater percentages of the total root mass in the bottom half of the soil profile, although the difference was significant $(P<0.01)$ only for Pumpelly's brome (Fig. 3). As a group, the warm-season grasses were twice as tall as the cool-season grasses, primarily because they were flowering. In Expt. 2, little bluestem, indiangrass, and nimblewill were similar to red fescue in height but the plants were stunted as a result of premature flowering. Expt. 3 was planted in early summer and all of the warm-season grasses were significantly taller than red fescue at harvest. Red fescue regularly reaches heights of 60 to $90 \mathrm{~cm}$ when the culms are included (Barkworth et al., 2007). Plant height fell within this range for little bluestem and purple lovegrass (Fig. 3), and observations on the roadsides confirm that these species are not significantly taller than red fescue when at the same growth stage. Both species rooted to the bottom of the columns in Expt. 3 and had significantly larger root systems and a greater percentage of roots in the bottom half of the soil profile than red fescue (Fig. 3).

Roadside grasses in New England are mowed approximately once a month from June through October to a height of $\approx 3$ inches $(7.6 \mathrm{~cm})$. Mowing is done for aesthetic reasons and to prevent the grasses from becoming a fire hazard or accumulating windblown litter (RIDOT, 2004). Slopes steeper than 3:1 are left unmowed. Lowgrowing grassses are preferred to minimize mowings; ideally, any grasses substituted for red fescue would be similar in stature.

Based on the data presented here, the bromes, the wildryes, bottlebrush, perennial ryegrass, tall fescue, little bluestem, and purple lovegrass exhibit the best combination of deep rooting, even root distribution, and short stature. Both bromes exhibited significantly deeper rooting and a more balanced root distribution than red fescue. Smooth

Table 4. Plant size data for Expt. 3. ${ }^{\mathrm{z}}$

\begin{tabular}{lcccc}
\hline Species & Replications & Plant ht $(\mathrm{cm})$ & Rooting depth $(\mathrm{cm})$ & Root mass $(\mathrm{g})$ \\
\hline Big bluestem & 6 & 102.6 & 76.0 & 6.0 \\
Autumn bentgrass & 6 & 60.6 & 69.7 & 0.9 \\
Pumpelly's brome & 30 & 48.4 & 75.2 & 1.2 \\
Hairgrass & 10 & 34.0 & 58.5 & 0.5 \\
Hard fescue & 5 & 34.6 & 39.5 & 0.2 \\
Eastern bottlebrush & 6 & 38.9 & 76.0 & 2.0 \\
Virginia wildrye & 4 & 42.5 & 76.0 & 1.4 \\
Red fescue & 6 & 38.9 & 43.1 & 0.2 \\
Indiangrass & 6 & 115.8 & 76.0 & 5.5 \\
Tall fescue & 6 & 53.1 & 76.0 & 2.3 \\
Little bluestem & 6 & 81.5 & 76.0 & 2.1 \\
Nimblewill & 6 & 96.7 & 76.0 & 8.7 \\
Alkali grass & 5 & 36.8 & 39.5 & 0.3 \\
Switchgrass & 12 & 107.0 & 76.0 & 7.4 \\
Perennial ryegrass & 6 & 36.6 & 74.7 & 1.6 \\
Sideoats grama & 6 & 101.0 & 76.0 & 4.3 \\
Purple lovegrass & 5 & 66.8 & 76.0 & 1.5 \\
Prairie junegrass & 6 & 19.3 & 11.4 & 0.02 \\
Sand dropseed & 6 & 99.9 & 76.0 & 0.5 \\
\hline
\end{tabular}

${ }^{\mathrm{z}}$ All values are means; least significant difference values are 18.8, 14.6, and 1.3 for height, depth, and mass, respectively. brome was $17 \mathrm{~cm}$ taller than red fescue in Expt. 1; Pumpelly's brome was $10.5 \mathrm{~cm}$ taller in Expt. 3. Eastern bottlebrush was nearly equal in height to red fescue in all three experiments but had deeper roots; the difference in rooting depth was significant in Expts. 2 and 3. The other three wildryes gave similar results. Perennial ryegrass and tall fescue were similar in height to red fescue and at least some individuals rooted to the bottom of the columns in Expts. 2 and 3. However, the differences in rooting depth were not consistently significant, and root distribution was no better than for red fescue. Little bluestem rooted more deeply than red fescue in all three experiments; the difference was significant in Expts. 1 and 3. Root distribution was more balanced, particularly in Expts. 2 and 3. Neither species flowered in Expt. 1, and the plant heights differed by only $3.6 \mathrm{~cm}$. Purple lovegrass was included only in Expt. 3 because of complete germination failure in 2006. It rooted to the bottom of the column with an extremely even root distribution.

To be of use in stabilizing slopes, grasses must also be able to survive on the roadside. Eight of the 14 species in the back slope trial failed to survive the drought from mid-June until mid-Aug. 2007: Canada wildrye, common red fescue, Virginia wildrye, purple lovegrass, sand dropseed, sideoats grama, fringed brome (Bromus ciliatus L.), and slender wheatgrass [Elymus trachycaulus (Link) Gould ex Shinners]. The three Elymus species, fringed brome, and red fescue were replanted as part of the front slope trial. Sand dropseed and sideoats grama were replanted on the back slope as transplants in 2008; they again failed to survive. The only commercially available purple lovegrass seed was of the Florida ecotype; we attribute its failure to establish to a lack of adaptation because the native purple lovegrass ecotype is widespread along roadsides in Rhode Island (Brown and Sawyer, in preparation). The remaining six species in the trial established and persisted for at least two growing seasons (Fig. 4). The summer of 2008 was similar to 2007 except that the summer drought lasted only until the third week of July. Switchgrass, nimblewill, and panic grass had the best stands in Sept. 2008 (Fig. 4). The summer of 2009 was unusually wet and cold. Big bluestem had the best stand in August 2009, whereas the panic grass declined markedly and the nimblewill died out (Fig. 4). Stand densities for switchgrass, little bluestem, and indiangrass differed only slightly between 2008 and 2009. Switchgrass, indiangrass, and little bluestem were represented by multiple cultivars; differences between cultivars were not significant for either year.

All entries in the front slope trial established and survived the winter of 2007-2008 (Fig. 5). In Apr. 2008, prairie junegrass and tall fescue had the best cover with means of $76.7 \%$ and $75 \%$, respectively. Alkaligrass had the least cover with a mean of only $14.6 \%$. Cover decreased during May and June for all species except autumn bentgrass 


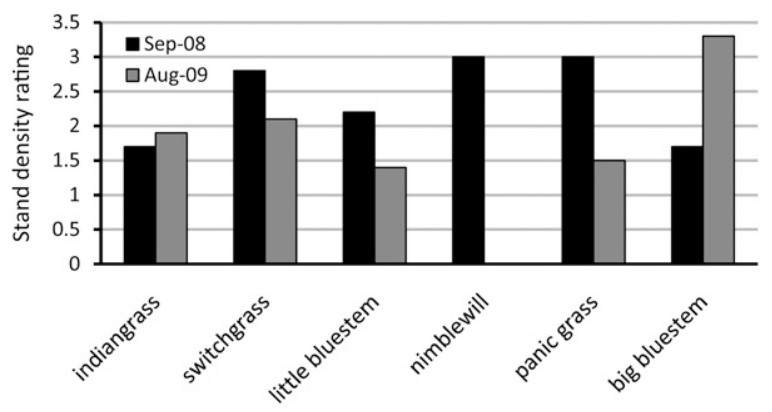

Fig. 4. Stand density for native grass species planted on the back slope along Rhode Island Route 4. Density was rated when grasses were in flower using a 0 to 4 scale in which 0 indicates no stand. Grasses were not mowed and received no maintenance after establishment.

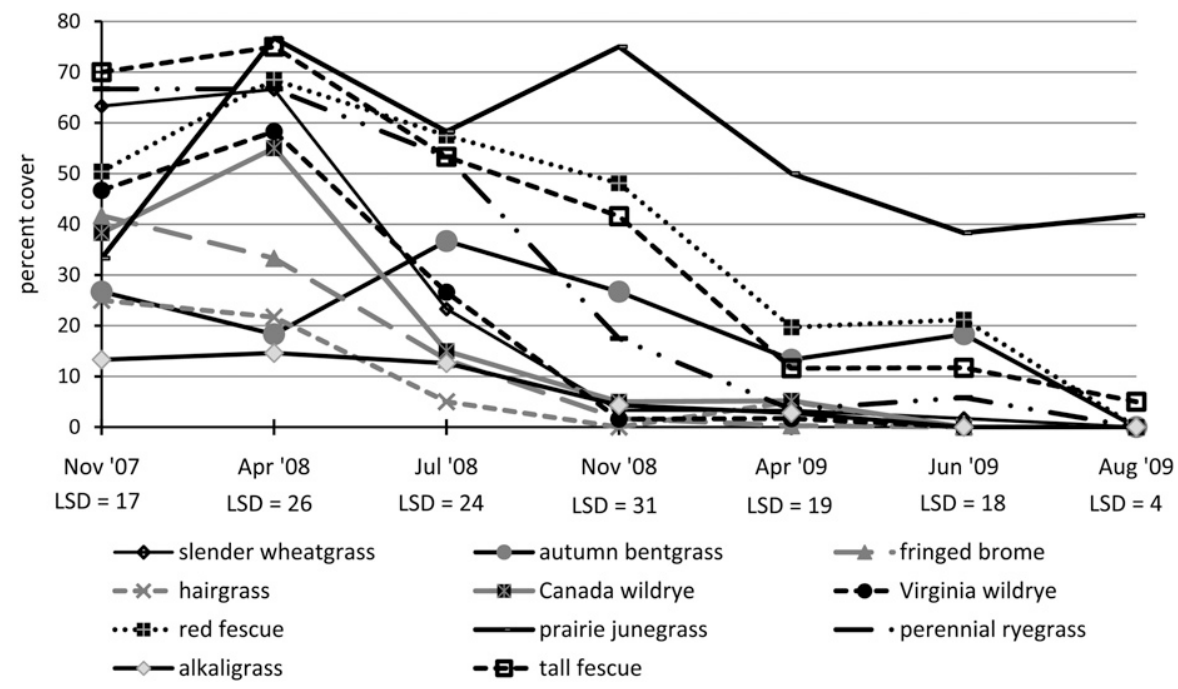

Fig. 5. Survival of grass species planted on the front slope along Rhode Island Route 4. Survival was measured through visual estimates of percent cover. Grasses were mowed by Department of Transportation crews but received no other maintenance after establishment.

as a result of nutrient deficiency and drought stress. July data were collected after 4 weeks of drought; species retaining at least $50 \%$ cover included prairie junegrass, red fescue, perennial ryegrass, and tall fescue. Autumn bentgrass had $36.7 \%$ cover, up from $18.3 \%$ in April. By Nov. 2008, prairie junegrass had regrown to $75 \%$ cover. All other species lost cover between July and November; six species decreased to less than 5\% cover (Fig. 5). Cover continued to decrease over the winter, and by Apr. 2009, only prairie junegrass exceeded $25 \%$ cover. Seven species were represented only by isolated clumps of grass. The final data were collected in Aug. 2009, by which point only the prairie junegrass and tall fescue plots could be recognized. Prairie junegrass retained over $40 \%$ cover; only a few scattered clumps of tall fescue remained. The front slope is a more stressful environment than the back slope; few perennial grasses survive long term and the dominant cover is smooth crabgrass [Digitaria ischaemum (Schreb.) Schreb. ex Muhl; Brown and Sawyer, in preparation].

Combining the results of the greenhouse and roadside trials indicates that little bluestem purple lovegrass and tall fescue are the best choices for anchoring roadside slopes. All species root deeply and are adapted to roadside conditions but are similar in stature to red fescue. Big bluestem, indiangrass, switchgrass, and bitter panic grass also combine deep rooting with adaptation to roadside conditions, but they were significantly taller than red fescue. These grasses are likely to be too tall for use on mowed roadsides. However, to the extent that populations of these species differ in height, the moderate correlation values suggest that selection for deep rooting coupled with reduced topgrowth would be effective in developing cultivars better suited to roadside use. Kim et al. (1999) found that plant height and rooting depth were not correlated among cultivars of tall fescue, and Bonos et al. (2004) found that both tall fescue and perennial ryegrass responded to selection for increased rooting depth coupled with maintenance of mean shoot growth.

This work should be useful as a guide in choosing grass species to stabilize slopes. All of the recommended species are either bunchgrasses or weakly rhizomatous with at best slow vegetative spread (USDA-NRCS, 2009). Little bluestem and purple lovegrass are warm-season (C4) grasses and dormant from October through May. Thus, the best way to use these grasses would be as a mix with red fescue and other shallow-rooted cool-season grasses with rapid vegetative spread and minimal winter dormancy. The deep-rooted species would anchor the slope, whereas the rapidly spreading species prevented surface erosion, slowed runoff, and provided the green roadsides desired by the public. Use of a mix of species would also reduce costs, because seed of little bluestem and purple lovegrass is substantially more expensive than seed of red fescue and other traditional turfgrasses and a mix would permit the little bluestem and purple lovegrass to be seeded at reduced rates. Another option would be to use tall fescue, which is a coolseason grass and relatively inexpensive. However, tall fescue is an introduced species that is considered invasive in several states, although not in New England (Mehrhoff et al., 2009; USDA-NRCS, 2009).

\section{Literature Cited}

Barkworth, M.E., K.M. Capels, S. Long, L.K Anderton, and M.B. Piep. 2007. Magnoliophyta: Commelinidae (in part): Poaceae, part 1. Oxford University Press, New York, NY.

Beard, J.B. 1989. Turfgrass water stress: Drought resistance components, physiological mechanisms, and species-genotype diversity, p. $23-$ 28. In: Takatoh, H. (ed.). Sixth International Turfgrass Research Conference, Japanese Society of Turfgrass Science and the International Turfgrass Society, Tokyo, Japan.

Bonos, S.A., D. Rush, K. Hignight, and W.A Meyer. 2004. Selection for deep root production in tall fescue and perennial ryegrass. Crop Sci. 44:1770-1775.

Clinton, W.J. 1999. Memorandum for the heads of executive departments and agencies of April 26, 1994, p. 596-597. In: Harper-Lore, B.L. (ed.). Roadside use of native plants. U.S. Department of Transportation Federal Highway Administration, Washington, DC.

Elliott, F.C. 1949. Bromus inermis and B. pumpellianus in North America. Evolution 3: 142-149.

Gray, D.H. and R.B. Sotir. 1996. Biotechnical and soil bioengineering slope stabilization: A practical guide for erosion control John Wiley \& Sons, Inc., New York, NY.

Harper, J., M. Jones, and N. Sackville Hamilton. 1991. The evolution of roots and the problems of analysing their behaviour, p. 3-22. In: Atkinson, D. (ed.). Plant root growth: An ecological perspective. Blackwell Scientific Publications, Oxford, UK.

Hoagland, D. and D. Arnon. 1950. The water culture method for growing plants without soil. California Agricultural Experiment Station Circular 347:1-32.

Kim, K.-N., R.C. Shearman, and T.P. Riordan. 1999. Top growth and rooting responses of tall fescue cultivars grown in hydroponics. Crop Sci. 39:1431-1434.

Mehrhoff, L.J., J.A. Silander, Jr., S.A. Leicht, E.S. Mosher, and N.M. Tabak. 2009. IPANE: Invasive plant atlas of New England. Department of Ecology \& Evolutionary Biology, University of Connecticut, Storrs, CT. 15 Oct. 2009. $<$ http://www.ipane.org $>$. 
RIDOT. 2004. Standard specifications for road and bridge construction. Rhode Island Department of Transportation, Providence, RI.

SAS. 2007. SAS/STAT software. SAS Institute, Cary, NC.

Schaeffer, J.A., G.A. Jung, and U.R. Narem. 1994. Root and shoot characteristics of prairie grass compared to tall fescue and smooth brome grass during establishment. New Zealand Journal of Agricultural Research 37:143-151.
Simon, A. and A.J.C. Collison. 2002. Quantifying the mechanical and hydrologic effects of riparian vegetation on streambank stability. Earth Surf. Process. Landf. 27:527546.

Sprague, H.B. 1933. Root development of perennial grasses and its relation to soil conditions. Soil Sci. 36:189-209.

Stuckey, I.H. 1941. Seasonal growth of grass roots. Amer. J. Bot. 28:486-491.
USDA-NRCS. 2009. The PLANTS database, National Plant Data Center. 15 Oct. 2009. $<$ http://www.plants.gov $>$.

Weaver, J.E. 1968. Prairie plants and their environment. University of Nebraska Press, Lincoln, NE.

Wright, W.R. and E.H. Sautter. 1988. Soils of Rhode Island landscapes. University of Rhode Island Agricultural Experiment Station. 